\title{
Pulmonary function studies in patients with farmer's lung
}

\author{
J . V. W I L L I A M S
}

From the Institute of Diseases of the Chest and Brompton Hospital, London

The inhalation of mouldy hay, grain, or straw produces in certain individuals the respiratory illness known as farmer's lung (Campbell, 1932; Fawcitt, 1938a and b). It is characterized by dyspnoea, fever, malaise, basal crepitations, and later diffuse reticulo-nodular chest radiographic shadowing, the acute and subacute phases described by Fuller (1953). Lung biopsies taken when this illness is subsiding show an acute granulomatous pneumonitis (Frank, 1958; Totten, Reid, Davis, and Moran, 1958; Baldus and Peter, 1960; Seal, 1962). Repeated episodes produce pulmonary fibrosis, bronchiectasis, and emphysema.

The diagnosis of this disease is usually made on a history of exposure to the dust and the presence of the characteristic clinical and radiological appearances. Difficulty in diagnosis may occur, as other respiratory illnesses, e.g., bronchitis and asthma, may all be worse after exposure to a dusty atmosphere. Further, symptoms usually occur hours after inhalation of the dust. This may make the correlation of the patient's illness with his occupation difficult.

The study described in this paper was made in 1959-1960 on patients with farmer's lung who had previously been exposed to mouldy hay obtained during the wet summer of 1958 in south-west England. Data are presented of some of the main lung function changes in these patients. An attempt is made to relate these functional changes to some of the clinical and radiological findings, and also to assess their value in the diagnosis and the estimation of disability in this condition.

\section{PREVIOUS PULMONARY FUNCTION STUDIES}

Most reports on lung function studies in patients with farmer's lung have been observations on ventilatory function. Studdert (1953) observed no change in the vital capacities of his patients over one to five years. Frank (1958) noted a permanent reduction in vital capacity in some patients and concluded that irreversible lung damage had occurred. He found high or normal vital capacities in some patients who nevertheless had effort dyspnoea. Pestalozzi (1957) described one patient whose vital capacity fell by $20 \%$ after exposure to hay dust. Brown, Parrot, and Porter (1958) and Cooper and Greenaway (1961) each reported one patient with a slight impairment in vital capacity and no significant bronchial airway obstruction, while Baldus and Peter (1960) described similar findings in two patients.

Totten et al. (1958) found arterial oxygen desaturation at rest in addition to low vital capacities in two patients. The inhalation of oxygen produced $100 \%$ arterial saturation.

Dickie and Rankin (1958) mention very briefly the physiological abnormalities found in their patients. In the acute episodes arterial hypoxia occurred due to impaired pulmonary diffusion and abnormal ventilation-perfusion relations. After recovery from the acute illness, pulmonary hyperinflation with a significant increase in residual capacity and functional residual capacity occurred with a moderate reduction in maximal breathing capacity, timed vital capacity, and expiratory flow rates. They concluded that these findings confirmed their clinical impression of obstruction in the smaller bronchi and bronchioles.

Staines and Forman (1961) had reports in their survey of reduced peak expiratory flow readings during and after the acute illness in nine patients. They thought the Wright peak flow meter useful in assessing the severity and progress of the illness. They also had reports of one patient with a normal chest radiograph and a vital capacity of $50 \%$ normal, and of a patient with impairment in both ventilatory function and intrapulmonary mixing efficiency.

Details of abnormalities in pulmonary function have been recorded in few patients with farmer's lung. Recently interest has been shown in the condition. Work has been performed on it at several centres in the British Isles and in America. 


\section{SUBJECTS}

Sixteen patients with farmer's lung were studied (reference numbers 1 to 16). They had all recovered from the acute illness and had had no contact with mouldy hay for at least three weeks. All were admitted to hospital for tests with the exception of patient 16 . Patient 8 had only farmed for 10 years, but the others had all been concerned with farming since childhood. Chest radiographs taken during the acute illness all showed the characteristic bilateral diffuse shadowing (the films of 15 patients were seen).

\section{METHODS}

CLINICAL ASSESSMENT Dyspnoea was assessed both by interrogation and by observation of the patient's activities while in hospital. The patients were graded according to their exercise tolerance, irrespective of the results of the pulmonary function tests.

Group 0 These patients could perform normal and strenuous activities without undue dyspnoea when compared with a normal person of the same age and sex.

Group I Effort tolerance was judged to be slightly below that of a normal person. The patient could climb 24 stairs at a moderate speed but not quickly. No symptoms were present walking on the flat.

Group II In this group 24 stairs could be climbed only very slowly. The patient could only walk one mile on the flat at his or her own speed.

Group III These patients could not climb 24 stairs and could not walk more than 400 yards at their own speed.

Chest auscultation was performed and discontinuous adventitious sounds (crepitations) were graded as few $( \pm)$, moderate $(+)$, or many $(++)$. Present and past chest radiographs were examined.

PULMONARY FUNCTION STUDIES Resting minute volume (M.V.) was measured using a vane anemometer (Wright, 1955). The patient rested for at least 15 minutes before the test. Resting minute volume per square metre body surface area was calculated and compared with normal values (Baldwin, Cournand, and Richards, 1948). Forced vital capacity (F.V.C.), forced expiratory volume in 1 second (F.E.V.1), and maximum voluntary ventilation (M.V.V.) were measured with a light spirometer similar to that described by Bernstein, D'Silva, and Mendel (1952). The mean of three consistent readings was taken. The increase in F.E.V.1 and F.V.C. five minutes after the inhalation of a $1 \%$ isoprenaline aerosol was used as a measure of reversible air-flow obstruction. The indirect maximum breathing capacity (M.B.C.) was calculated from the F.E.V.1 by multiplying it by a factor of 35 (Gandevia and Hugh-Jones, 1957). The ratio $\frac{\text { F.E.V.1 }}{\text { F.V.C. }}$ was calculated, and values below $75 \%$ were regarded as abnormal. The vital capacity (V.C.) was also measured. The functional residual capacity (F.R.C.), total lung capacity (T.L.C.), and residual volume (R.V.) were determined using the closedcircuit helium dilution method (Gilson and HughJones, 1949). Normal values were predicted on the basis of the simplified formulae of Needham, Rogan, and McDonald (1954). A rough measurement of the mixing efficiency was obtained from the total time the helium concentration took to fall to the equilibrium level. (Up to three minutes was regarded as normal, three to seven minutes as slight impairment, and above seven minutes as marked impairment.) Peak expiratory flow rate (P.E.F.R.) measurements were made using a Wright peak flow meter (Wright and McKerrow, 1959). The mean of three consistent readings was taken. They were compared with normal values, according to age and sex, for this particular laboratory.

The steady state carbon monoxide diffusing capacity (DLco) was estimated at rest and on exercise. The apparatus and method described by MacNamara. Prime, and Sinclair (1959) were used, and the normal values they obtained were used for comparison.

Static lung compliance was calculated from simultaneous measurements of tidal volume and transpulmonary pressure obtained from oesophageal and mouth pressures. The apparatus used by Davies, Williams, and Wood (1962) was used. The 'specific compliance' or ratio compliance/F.R.C. was calculated (Lim and Luft, 1959). The predicted normal range used for comparison was that of Marshall (1957). Dynamic compliance estimations, with the patient breathing at his own usually fast rate, were also made.

Arterial blood was collected by brachial artery puncture at rest, sometimes on exercise, and after breathing pure oxygen for 10 minutes. The techniques of Van Slyke and Neill (1924) were used for measuring the oxygen content, oxygen capacity, and carbon dioxide content of arterial blood. The estimation of $p \mathrm{H}$ using a glass electrode enabled the partial pressure of carbon dioxide $\left(\mathrm{PCO}_{2}\right)$ and plasma bicarbonate to be calculated from nomograms (Van Slyke and Sendroy, 1928). The arterial oxygen saturation was determined, and approximate values for the partial pressures of oxygen $\left(\mathrm{Po}_{2}\right)$ were calculated from the arterial oxygen dissociation curve. Arterial blood $\mathrm{PCO}_{2}$ was also measured by the rebreathing technique of Campbell and Howell (1960). Normal values for arterial blood gases were obtained from the National Academy of Sciences Handbook of Respiration (1958).

\section{RESULTS}

Although the 16 patients had recovered from their acute illnesses, 12 patients had some residual effort dyspnoea. Table I gives some details of these patients at the time of testing. Fig. 1 summarizes the main pulmonary function changes observed. 
FIG. 1. Summary of main changes in lung function in patients with farmer's lung studied. (Dots within the rectangles are within the normal range, those above and below are high and low values respectively.)

TA B LE I

FARMER'S LUNG : CHARACTERISTICS AT THE TIME OF

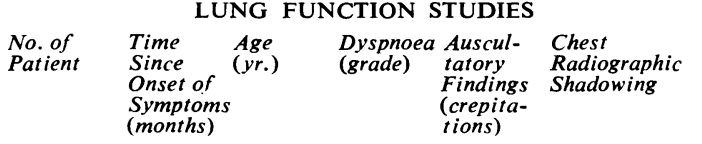

\begin{tabular}{|c|c|c|c|c|c|}
\hline & & \\
\hline \multicolumn{4}{|l|}{ Males } & & \\
\hline 3 & 6 & 37 & 0 & 0 & 0 \\
\hline 5 & $\begin{array}{l}3 \\
5\end{array}$ & $\begin{array}{l}50 \\
30\end{array}$ & $\frac{1}{2}$ & $\overline{\overline{0}}$ & $\begin{array}{l}0 \\
0\end{array}$ \\
\hline 7 & 18 & 54 & $\frac{2}{2}$ & 0 & $\begin{array}{l}0 \\
0\end{array}$ \\
\hline & & & & & Bilat.diffuse \\
\hline 10 & $\begin{array}{r}5 \\
39\end{array}$ & $\begin{array}{l}25 \\
36\end{array}$ & $\begin{array}{l}0 \\
0\end{array}$ & $\begin{array}{l}0 \\
0\end{array}$ & $\begin{array}{c}0 \\
\text { Bilat. diffuse }\end{array}$ \\
\hline & & & & & reticulo-nodul \\
\hline 15 & $\begin{array}{l}60 \\
48\end{array}$ & $\begin{array}{l}38 \\
49\end{array}$ & 1 & 0 & Bilat. diffuse \\
\hline 16 & 252 & 35 & 0 & 0 & \\
\hline Females & (mild) & $(25-56)$ & & & \\
\hline $\begin{array}{l}1 \\
4\end{array}$ & $\begin{array}{r}6 \\
48+\end{array}$ & $\begin{array}{l}50 \\
57\end{array}$ & $\frac{1}{2}$ & $0_{0}^{0}$ & 0 \\
\hline 8 & 3 & 52 & 3 & + & minimal patc \\
\hline 1 & & & 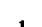 & & reticulo-nodular \\
\hline & 3 & 43 & 1 & 0 & $\begin{array}{l}\text { Heavy vascular } \\
\text { markinos }\end{array}$ \\
\hline 14 & 108 & $\begin{array}{c}41 \\
(41-57)\end{array}$ & 3 & + & $\begin{array}{l}\text { Bilat. diffuse } \\
\text { pulm. fibrosis }\end{array}$ \\
\hline
\end{tabular}

VENTILATORY FUNCTION The results are seen in Table II. Disturbances in ventilatory function were not marked. Low values were found for the M.B.C. in three patients, M.V.V. in five patients, P.E.F.R. in six patients, and V.C. in three patients. Only in patient 14 were they severe.
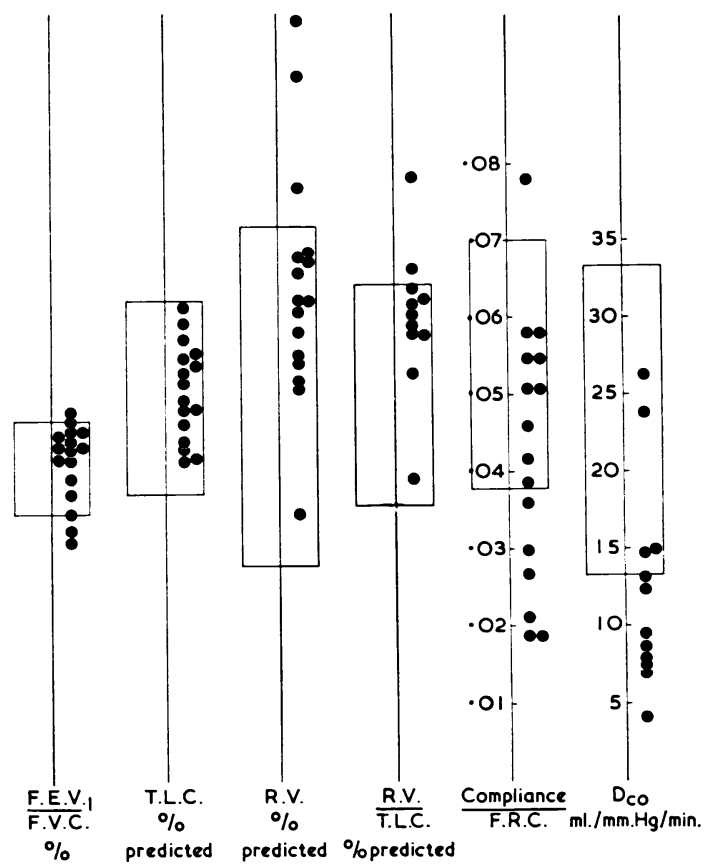

The F.E.V.1/F.V.C. ratio was below $75 \%$ in only two patients, the range being 63 to $96 \%$. The improvement in F.E.V.1 and F.V.C. after inhalation of isoprenaline was negligible compared with the results obtainable in asthmatics. Reversible bronchial airway obstruction is thus unimportant in these patients.

The resting M.V. was over $91 . / \mathrm{min}$. in nine patients. The high resting M.V. when related to surface area in 12 patients may have been partly caused by anxiety.

STATIC LUNG volumes Table III shows these results. The total lung capacity was within the normal range in all patients except in patient 10 where it was just above the normal range. The residual volume was abnormally high in two patients (5 and 8 ). In only patient 2 was it below the predicted mean. The ratio $\frac{\text { R.V. }}{\text { T.L.C. }}$ was high in four patients $(6,8,9$, and 14$)$. The functional residual capacities were high in six patients $(1,3,5,8,10$, and 12). The time for even helium distribution suggested a definite impairment in pulmonary gas mixing in patient 8 and slight impairment in patients 2 and 14 .

CARBON MONOXIDE DIFFUSING CAPACITY Twelve patients had estimations of the $\mathrm{DL}_{\text {co }}$ at rest and on 
TABLE II

FARMER'S LUNG: RESULTS OF VENTILATORY FUNCTION TESTS

\begin{tabular}{|c|c|c|c|c|c|c|c|c|c|c|c|c|}
\hline \multirow{2}{*}{$\begin{array}{l}\text { No. of } \\
\text { Patient }\end{array}$} & \multirow{2}{*}{$\begin{array}{l}\text { M.V. } \\
\text { Resting } \\
(l . \text { min. })\end{array}$} & \multirow{2}{*}{$\begin{array}{l}\frac{M \cdot V .}{S \cdot A .} \\
\left(\frac{I . \min .}{m \cdot .^{2}}\right)\end{array}$} & \multirow{2}{*}{$\begin{array}{l}\text { F.E.V.V }{ }_{1} \\
\text { F.V.C. } \\
\text { Ratio } \\
(\%)\end{array}$} & \multicolumn{2}{|c|}{$\begin{array}{l}\% \text { Change after } \\
\text { Isoprenaline }\end{array}$} & \multicolumn{2}{|l|}{ M.B.C. } & \multicolumn{2}{|l|}{ M.V.V. } & \multicolumn{2}{|l|}{$V . C}$. & \multirow{2}{*}{$\begin{array}{l}\text { P.E.F.R. } \\
\text { (l./min. })\end{array}$} \\
\hline & & & & F.E.V. $\cdot_{1}$ & F.V.C. & l. $\min$ & $\begin{array}{l}\% \\
\text { Predicted }\end{array}$ & $l . / \min$ & $\begin{array}{l}\% \\
\text { Predicted }\end{array}$ & Litres & $\begin{array}{l}\% \\
\text { Predicted }\end{array}$ & \\
\hline $\begin{array}{c}\text { Males } \\
2 \\
3 \\
5 \\
6 \\
7 \\
9 \\
10 \\
12 \\
13 \\
15 \\
16 \\
\text { Mean }\end{array}$ & $\begin{array}{r}7.0 \\
9.6 \\
13.0 \\
16.2 \\
14.0 \\
14.1 \\
8.0 \\
13.5 \\
12.3 \\
9.0 \\
6.8\end{array}$ & $\begin{array}{l}4 \cdot 0 \\
5 \cdot 6^{*} \\
7 \cdot 4^{*} \\
8 \cdot 6^{*} \\
8 \cdot 7^{*} \\
8 \cdot 8^{*} \\
4 \cdot 5^{*} \\
6 \cdot 8^{*} \\
6 \cdot 8^{*} \\
5 \cdot 1^{*} \\
3 \cdot 8^{*} \\
6 \cdot 4^{*}\end{array}$ & $\begin{array}{l}63^{*} \\
96 \\
90 \\
87 \\
84 \\
91 \\
84 \\
89 \\
70^{*} \\
65^{*} \\
87\end{array}$ & $\begin{array}{r}+3 \\
+4 \\
+1 \\
0 \\
-4 \\
-3 \\
+3 \\
+4 \\
+4 \\
+9 \\
+3 \\
+2\end{array}$ & $\begin{array}{r}+3 \\
+4 \\
+2 \\
-2 \\
+6 \\
+1 \\
0 \\
+3 \\
+3 \\
+3 \\
+3 \\
+2\end{array}$ & $\begin{array}{r}77 \\
109 \\
116 \\
100 \\
81 \\
72 \\
126 \\
110 \\
91 \\
77 \\
116\end{array}$ & $\begin{array}{c}71 \\
87 \\
105 \\
81 \\
77 \\
70 \\
90 \\
87 \\
73 \\
69 * \\
91 \\
82\end{array}$ & $\begin{array}{r}74 \\
143 \\
99 \\
98 \\
104 \\
70 \\
132 \\
104 \\
96 \\
59 \\
125\end{array}$ & $\begin{array}{c}69^{*} \\
113 \\
90 \\
80 \\
99 \\
68^{*} \\
94 \\
82 \\
77 \\
53^{*} \\
98 \\
84\end{array}$ & $\begin{array}{l}3.65 \\
4.05 \\
3.95 \\
3.45 \\
2.85 \\
2.31 \\
5.33 \\
3.91 \\
3.88 \\
3.40 \\
4.00\end{array}$ & $\begin{array}{c}97 \\
103 \\
103 \\
80 \\
91 \\
70^{*} \\
113 \\
80 \\
92 \\
86 \\
92 \\
92\end{array}$ & $\begin{array}{l}370^{*} \\
553 \\
480 \\
410^{*} \\
310^{*} \\
450 \\
600 \\
560 \\
465 \\
410^{*} \\
600 \\
473\end{array}$ \\
\hline
\end{tabular}

\begin{tabular}{|c|c|c|c|c|c|c|c|c|c|c|c|c|}
\hline $\begin{array}{l}\text { Normal } \\
\text { range }\end{array}$ & & $2 \cdot 6-4 \cdot$ & & & & & $70-130$ & & $70-130$ & & $78-122$ & \\
\hline $\begin{array}{c}\text { Females } \\
1 \\
4 \\
8 \\
11 \\
14 \\
\text { Mean }\end{array}$ & $\begin{array}{l}9 \cdot 3 \\
7 \cdot 0 \\
8 \cdot 0 \\
8 \cdot 5 \\
7 \cdot 9\end{array}$ & $\begin{array}{l}5 \cdot 6^{*} \\
4 \cdot 2^{2} \\
5 \cdot 0^{*} \\
5 \cdot 8^{*} \\
4 \cdot 5^{*} \\
5 \cdot 0^{*}\end{array}$ & $\begin{array}{l}87 \\
94 \\
75 \\
79 \\
91\end{array}$ & $\begin{array}{l}+ \\
-2 \\
+3 \\
+4 \\
+7 \\
+3\end{array}$ & $\begin{array}{r}+5 \\
-1 \\
0 \\
0 \\
+6 \\
+2\end{array}$ & $\begin{array}{l}77 \\
67 \\
42 \\
61 \\
35\end{array}$ & $\begin{array}{l}99 \\
92 \\
55^{*} \\
73 \\
42^{*} \\
72\end{array}$ & $\begin{array}{l}80 \\
50 \\
40 \\
57 \\
27\end{array}$ & $\begin{array}{c}103 \\
68 \\
52^{*} \\
69 \\
32^{*} \\
65\end{array}$ & $\begin{array}{l}2.98 \\
1.95 \\
2.05 \\
2 \cdot 21 \\
1 \cdot 20\end{array}$ & $\begin{array}{c}107 \\
76 \\
69 * \\
91 \\
40^{*} \\
77\end{array}$ & $\begin{array}{l}390 \\
370 \\
200^{*} \\
325 \\
220^{*} \\
301\end{array}$ \\
\hline
\end{tabular}

Normal

range

$2 \cdot 5-4 \cdot 3$

$67-133$

$67-133$

74-126

Mean (male and female) $83+3+3$

* Abnormal results

TABLE III

FARMER'S LUNG: RESULTS OF LUNG VOLUME AND COMPLIANCE STUDIES

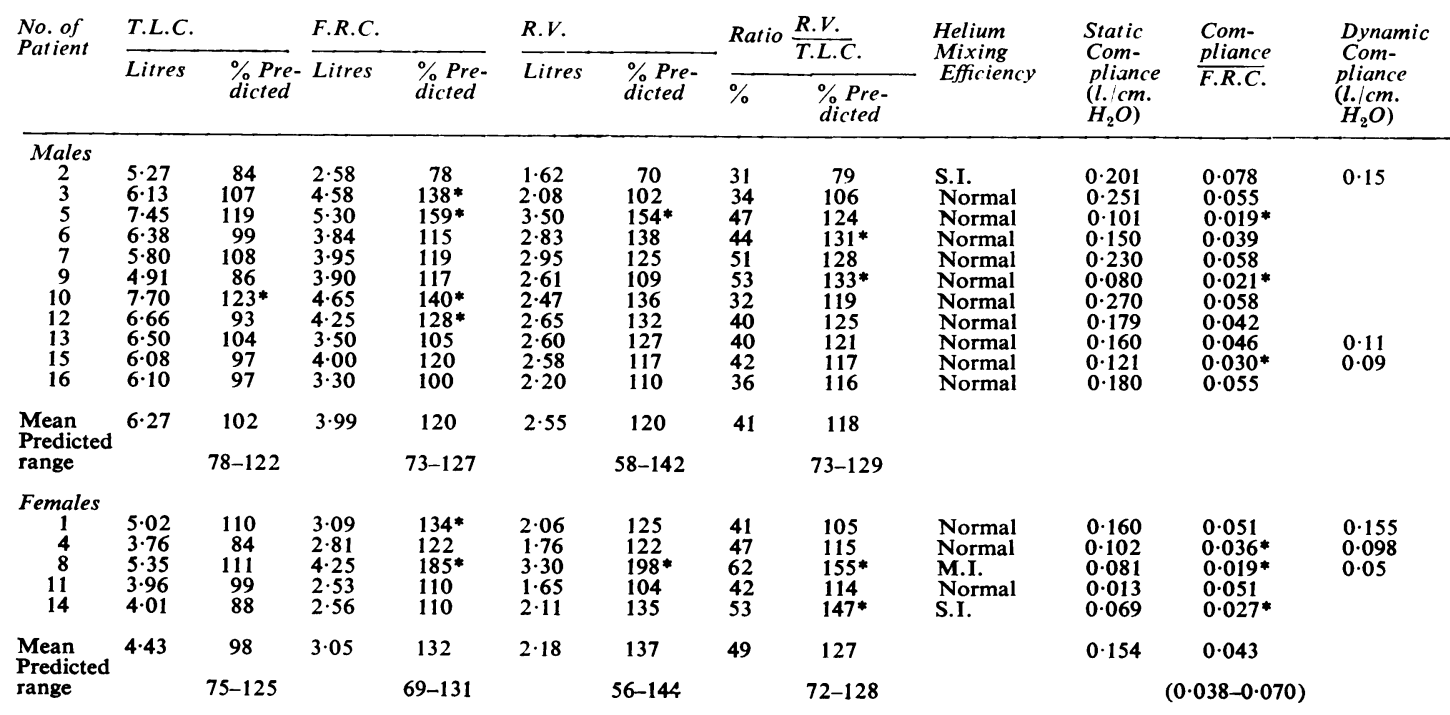

* Abnormal result. S.I., slight impairment; M.I., moderate impairment 
TABLE IV

FARMER'S LUNG: RESULTS OF DIFFUSING CAPACITY ESTIMATIONS (STEADY STATE CO METHOD)

\begin{tabular}{|c|c|c|c|c|}
\hline \multirow{2}{*}{$\begin{array}{l}\text { No. of } \\
\text { Patient }\end{array}$} & \multicolumn{2}{|l|}{ At Rest } & \multicolumn{2}{|c|}{ On Exercise } \\
\hline & $\begin{array}{l}\text { DLco } \\
(\mathrm{ml} / \mathrm{min} . / \\
\mathrm{mm} . \mathrm{Hg})\end{array}$ & $\begin{array}{l}M . V . \\
(l . / \min .)\end{array}$ & $\begin{array}{l}\text { DLco } \\
(\mathrm{ml} . / \mathrm{min} . / \\
\mathrm{mm} . \mathrm{Hg})\end{array}$ & $\underset{(l . / \min .)}{M . V .}$ \\
\hline $\begin{array}{r}1 \\
2 \\
6 \\
7 \\
8 \\
9 \\
11 \\
12 \\
13 \\
14 \\
15 \\
16\end{array}$ & $\begin{array}{c}12 \cdot 5^{*} \\
13 \cdot 1^{*} \\
8.8^{*} \\
7.9^{*} \\
4 \cdot 1^{*} \\
9 \cdot 6^{*} \\
14 \cdot 8 \\
23 \cdot 8 \\
15.0 \\
7 \cdot 2^{*} \\
12.4^{*} \\
26.3\end{array}$ & $\begin{array}{r}7 \cdot 9 \\
6 \cdot 3 \\
8 \cdot 8 \\
11 \cdot 5 \\
3 \cdot 7 \\
9 \cdot 3 \\
8 \cdot 5 \\
14 \cdot 3 \\
16 \cdot 9 \\
10 \cdot 0 \\
10 \cdot 3 \\
13 \cdot 2\end{array}$ & $\begin{array}{c}16.9^{*} \\
18.8^{*} \\
15.6^{*} \\
14.7^{*} \\
9.9^{*} \\
13 \cdot 2^{*} \\
12.0^{*} \\
28.0 \\
22.3 \\
10.1^{*} \\
25.4 \\
29.0\end{array}$ & $\begin{array}{l}15 \cdot 5 \\
14 \cdot 2 \\
21 \cdot 8 \\
16 \cdot 3 \\
12.5 \\
23.4 \\
18 \cdot 0 \\
16.8 \\
23.0 \\
19 \cdot 5 \\
25 \cdot 1 \\
24.0\end{array}$ \\
\hline $\begin{array}{l}\text { Mean } \\
\text { Normal } \\
\text { range }\end{array}$ & $\begin{array}{c}13 \cdot 0 \\
(13 \cdot 4-33 \cdot 2 \\
\text { Mean } 23 \cdot 3)\end{array}$ & & $\begin{array}{l}18 \cdot 0 \\
1 \cdot 2-43 \cdot 8 \\
\text { Mean } 32 \cdot 5)\end{array}$ & \\
\hline
\end{tabular}

* Abnormally low result

exercise (Table IV). The two patients (12 and 16) with no residual dyspnoea had normal diffusing capacities. The others all had impairment in the diffusing capacity, either at rest or on effort.

ARTERIAL BLOOD GAS ESTIMATIONS Arterial oxygen desaturation at rest was present in all patients studied (Table V). It increased on exercise. Breathing pure oxygen for 10 minutes raised the oxygen saturation to $100 \%$ in three patients. Correspondingly, the arterial $\mathrm{Po}_{2}$ was low in all patients studied. The arterial $\mathrm{PCO}_{2}$ was normal in five patients, low in patient 9 , and slightly raised in patient 8. The arterial blood $p \mathbf{H}$ varied between 7.32 and 7.43 in the seven patients studied. The plasma bicarbonate was either normal or low in these patients.

Patients 2 and 7 had normal arterial partial pressures of carbon dioxide when this was estimated by the rebreathing method $(45$ and $40 \mathrm{~mm}$. $\mathrm{Hg}$, respectively).

MECHANICAL PROPERTIES The static lung compliance, the ratio static compliance/F.R.C. (or 'specific compliance'), and the dynamic compliance were measured (Table III). The 'specific compliance' was low in six patients. In patients $2,8,13$, and 15 the dynamic compliance was much lower than the static compliance. This suggested that during normal respiration the lung was not expanding uniformly.

PULMONARY FUNCTION CHANGES IN RELATION TO DYSPNOEA Patients with a normal exercise tolerance $(3,10,12$, and 16$)$ had lung function tests which were probably within normal limits, apart from a slight increase in F.R.C. in three patients and a high M.V. in two patients. Those with abnormal exercise tolerance had lung function abnormalities (Table VI). It is seen that carbon

\section{TA B LE VI}

FARMER'S LUNG: PULMONARY FUNCTION ABNORMALITIES RELATED TO DYSPNOEA

\begin{tabular}{lll} 
& \multicolumn{2}{c}{$\begin{array}{c}\text { Abnormal Results in } \\
\text { Patients with: }\end{array}$} \\
\cline { 2 - 3 } & $\begin{array}{l}\text { Effort } \\
\text { Dyspnoea }\end{array}$ & $\begin{array}{c}\text { No Effort } \\
\text { Dyspnoea }\end{array}$ \\
\hline No. of patients & 12 & 4 \\
DLco either at rest or & $10 / 10$ & $0 / 2$ \\
on effort & $6 / 12$ & $0 / 4$ \\
Specific compliance & $3 / 12$ & $0 / 4$ \\
M.B.C. & $5 / 12$ & $0 / 4$ \\
M.V.V. & $3 / 12$ & $0 / 4$ \\
V.C. & $10 / 12$ & $2 / 4$ \\
High M.V. & $3 / 12$ & $0 / 4$ \\
F.E.V.1 ratio & $6 / 12$ & $0 / 4$ \\
F.V.C. & $0 / 12$ & $1 / 4$ \\
P.E.F.R. & $1 / 12$ & $1 / 4$ \\
T.L.C. & $3 / 12$ & $3 / 4$ \\
R.V. & $3 / 12$ & $0 / 4$ \\
F.R.C. & &
\end{tabular}

monoxide diffusing capacity and specific compliance are reduced in most of these patients, but there are relatively few changes in ventilatory function. Although the P.E.F.R. was low in six patients it was only markedly low in patients 7 , 8 , and 14.

Figs. 2 to 4 show that the severity of the effort dyspnoea is roughly proportional to the impairment in the DLco at rest. Effort dyspnoea and diminished static compliance were less closely re-

TABLE V

FARMER'S LUNG: RESULTS OF ARTERIAL BLOOD GAS ESTIMATIONS

\begin{tabular}{|c|c|c|c|c|c|c|c|c|}
\hline $\begin{array}{l}\text { No. of } \\
\text { Patient }\end{array}$ & $\begin{array}{l}\text { Oxygen } \\
\text { Capacity } \\
\text { (V.p.c.) }\end{array}$ & $\begin{array}{l}\text { Oxygen } \\
\text { Saturation } \\
(\%)\end{array}$ & $\begin{array}{l}\text { Oxygen } \\
\text { Saturation } \\
\text { Breathing } \mathrm{O}_{2} \\
(\%)\end{array}$ & $\begin{array}{l}\text { Carbon } \\
\text { Dioxide } \\
\text { Content } \\
\text { (V.p.c.) }\end{array}$ & $\mathrm{p} H$ & $\begin{array}{l}\mathrm{Po}_{2} \\
(\mathrm{~mm} . \mathrm{Hg})\end{array}$ & $\begin{array}{l}\mathrm{PCO}_{2} \\
(\mathrm{~mm} \cdot \mathrm{Hg})\end{array}$ & $\begin{array}{l}\text { Plasma } \\
\text { Bicarbonate } \\
\text { (m.M.L.) }\end{array}$ \\
\hline $\begin{array}{l}1 \\
4 \\
6 \\
6\end{array}$ & $\begin{array}{l}20 \cdot 8 \\
18 \cdot 6 \\
18 \cdot 8 \\
19 \cdot 3\end{array}$ & $\begin{array}{l}90 \\
89 \\
92 \\
85\end{array}$ & 100 & $\begin{array}{l}47 \cdot 5 \\
37 \cdot 8 \\
48 \cdot 6 \\
45 \cdot 2\end{array}$ & $\begin{array}{l}7 \cdot 43 \\
7 \cdot 32 \\
7 \cdot 41 \\
7 \cdot 42\end{array}$ & $\begin{array}{l}60 \cdot 0 \\
64 \cdot 0 \\
67 \cdot 0 \\
51 \cdot 0\end{array}$ & $\begin{array}{l}39 \cdot 0 \\
39 \cdot 0 \\
41 \cdot 5 \\
38 \cdot 5\end{array}$ & $\begin{array}{l}24 \cdot 0 \\
18 \cdot 5 \\
24 \cdot 5 \\
23 \cdot 0\end{array}$ \\
\hline $\begin{array}{r}7 \\
8 \\
9 \\
11\end{array}$ & $\begin{array}{l}20 \cdot 0 \\
19 \cdot 3 \\
21 \cdot 2 \\
22 \cdot 4\end{array}$ & $\begin{array}{l}93 \\
88 \\
89 \\
92\end{array}$ & $\begin{array}{l}100 \\
100\end{array}$ & $\begin{array}{l}45 \cdot 2 \\
48 \cdot 2 \\
36 \cdot 1 \\
44 \cdot 8\end{array}$ & $\begin{array}{l}7 \cdot 37 \\
7 \cdot 36 \\
7 \cdot 40 \\
7 \cdot 38\end{array}$ & $\begin{array}{l}71 \cdot 0 \\
60 \cdot 0 \\
59 \cdot 0 \\
70 \cdot 0\end{array}$ & $\begin{array}{l}42 \cdot 0 \\
49 \cdot 0 \\
32 \cdot 0 \\
43 \cdot 0\end{array}$ & $\begin{array}{l}22 \cdot 5 \\
24 \cdot 0 \\
19 \cdot 0 \\
23 \cdot 0\end{array}$ \\
\hline Normals & $16 \cdot 8-22 \cdot 9$ & $93 \cdot 5-97 \cdot 5$ & & $4 \cdot 6-50 \cdot 2$ & $7 \cdot 37-7 \cdot 46$ & $80-104$ & $36-45$ & $24 \cdot 0-29 \cdot 0$ \\
\hline
\end{tabular}




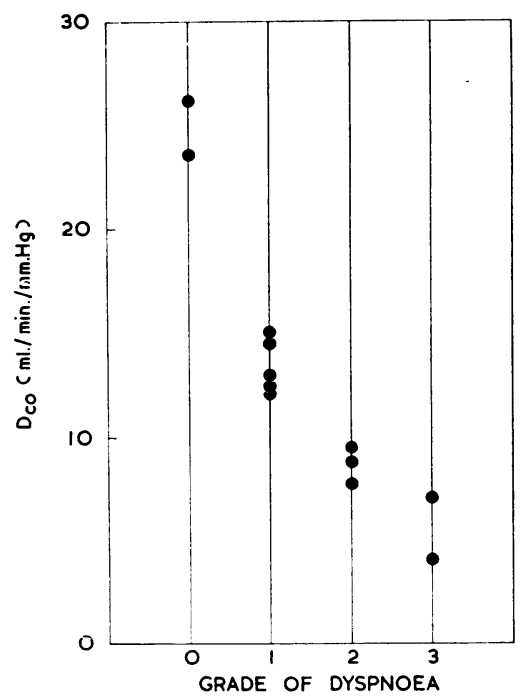

FIG. 2. The relation between the DLco at rest and the grade of dyspnoea.

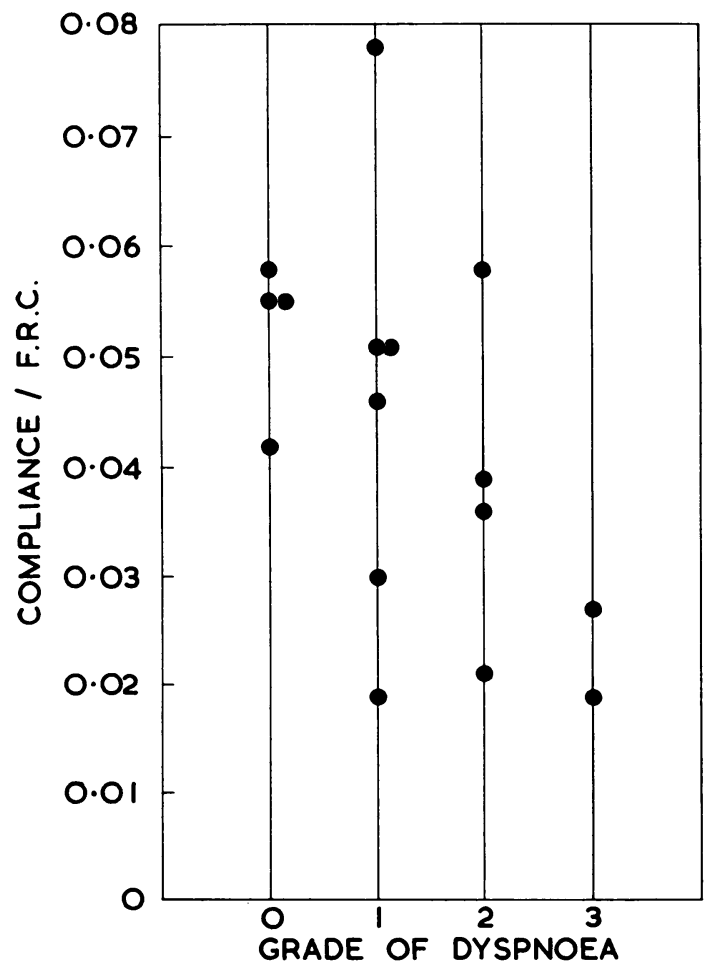

FIG. 3. The relation between the compliance/F.R.C. ratio and the grade of dyspnoea.

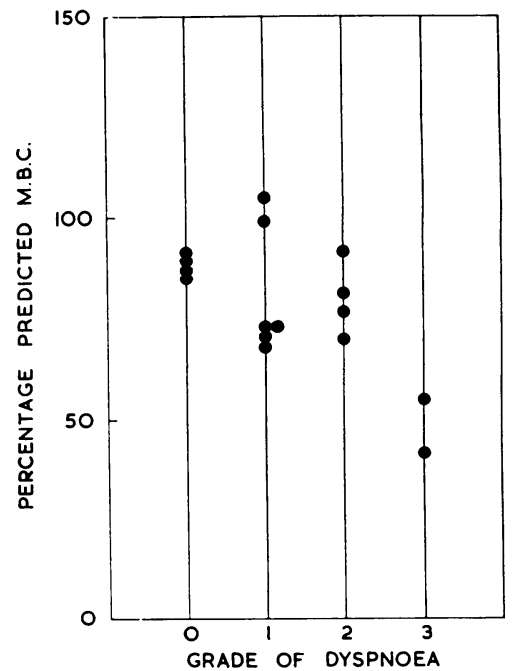

FIG. 4. The relation between the maximum breathing $₫$ capacity $(\%$ predicted $)$ and the grade of dyspnoea.

lated. There was least correlation between effort dyspnoea and impairment of the M.B.C.

CHEST RADIOGRAPHIC CHANGES AND FUNCTIONO STUDIES The 12 patients with persistent effort dyspnoea after their acute illnesses had pulmonary® radiographic shadowing at the time of the acute $\overrightarrow{\vec{B}}$ illnesses. When lung function tests were made, $\supset$ only six patients had abnormal chest radiographs.

TA B LE VII

FARMER'S LUNG: PULMONARY FUNCTION ABNOR-つ MALITIES IN BREATHLESS PATIENTS RELATED TOO RADIOLOGICAL FINDINGS

Abnormal Results when Chest Radiograph was:

$\overrightarrow{\text { Abnormal }} \longrightarrow \overrightarrow{\text { Normal }}$

No. of patients with

effort dyspnoea

Dico either at rest

or on effort

Specific compliance

V.C.

Resting M.V.

P.E.F.R.

$\begin{array}{ccc}6 & 6 & 0 \\ 55 & 55 \\ 56 & 16 \\ 3 / 6 & 06 \\ 46 & 16 \\ 56 & 56 \\ \begin{array}{c}\text { (only 2 } 6 \text { markedly } \\ \text { abnormal) }\end{array} & \begin{array}{c}\text { (only 1 } 6 \text { marked ly } \\ \text { abnormal) }\end{array}\end{array}$

There had been complete clearing of the shadows in the other six patients. The lung function abnormalities in these two groups of patients are shown in Table VII.

Patient 12 had an abnormal chest radiograph (bilateral diffuse reticulo-nodular shadowing) butō had practically normal pulmonary function (apart迎 from resting M.V. and F.R.C., which were both $\overrightarrow{\mathbb{D}}$ slightly raised). 


\section{DISCUSSION}

Patients with farmer's lung with persistent dyspnoea after the acute illness usually have a low diffusing capacity, normal or only slightly impaired ventilatory function, and no evidence of airflow obstruction. The terms 'alveolar-respiratory insufficiency' (Baldwin, Cournand, and Richards, 1949) and 'alveolar-capillary block' (Austrian, McClement, Renzetti, Donald, Riley, and Cournand, 1951) might describe these findings.

These terms were used to describe the clinical and physiological findings in some patients with diffuse pulmonary disease and evidence of impaired oxygen diffusion between the alveolus and the pulmonary capillary. The characteristic clinical features of this syndrome included dyspnoea, tachypnoea especially on effort, cyanosis usually after exercise, bilateral basal crepitations on chest auscultation, and no evidence of bronchiolar or bronchial airway obstruction. There was usually diffuse radiographic lung shadowing and histological evidence of lesions (usually fibrous, acute inflammatory, granulomatous, or neoplastic) at or near the alveolar-capillary septa. Pulmonary function studies showed hyperventilation at rest and on exercise, normal or only slightly reduced maximum breathing capacity, reduced static lung volumes, low or normal arterial carbon dioxide tension, arterial oxygen desaturation especially on exercise, normal or only slightly abnormal ventilation-perfusion relations, and a reduction in the pulmonary diffusing capacity for oxygen.

The clinical and histological features of farmer's lung described here are in keeping with this syndrome. The diffusing capacity measured by the carbon monoxide steady state method was impaired in all those patients studied with residual effort dyspnoea. Arterial oxygen desaturation was present at rest but became more marked on exercise, and breathing pure oxygen produced $100 \%$ saturation. The arterial $\mathrm{PCO}_{2}$ was usually normal. These results all suggest an abnormality of pulmonary diffusion. Most patients had normal maximum breathing capacities, high F.E.V.1/ F.V.C. ratios, and normal pulmonary mixing efficiencies. Resting ventilation was high in several patients. Impairment in diffusing capacity in these circumstances may be due to a reduction in size of the effective pulmonary membrane available for diffusion, i.e., the functioning alveoli in contact with pulmonary capillaries, or to an abnormality of the nature and increased thickness of this membrane. The latter was said to produce the physiological defect in the true alveolar-capillary block syndrome. An abnormal ventilation-perfusion relation might reduce the effective size of the diffusion membrane (as some alveoli may be ventilated but not perfused, and vice versa) and thus reduce diffusing capacity. Abnormal ventilation-perfusion imbalances have been shown to be responsible for the findings in many so-called alveolar-capillary block syndromes (Motley, 1958; Read and Williams, 1959). In the patients with farmer's lung studied, direct measurements of ventilation-perfusion relations were not made. Most patients had normal gas mixing, suggesting that the inspired air was evenly distributed throughout the lungs. The inhalation of pure oxygen produced $100 \%$ arterial oxygen saturation, suggesting that large venous to arterial shunts were not present. The low diffusing capacity observed in farmer's lung may nevertheless be partly caused by ventilation-perfusion imbalances in addition to the thickening of the alveolar walls observed (Seal, 1962).

Dickie and Rankin (1958) found evidence of pulmonary hyperinflation, moderate ventilatory impairment, and moderate airflow obstruction in their patients after the acute illness. In the patients I studied, pulmonary hyperinflation as shown by both raised residual volumes and functional residual capacities were seen in only two patients, though four patients in addition had slightly raised functional residual capacities. A slight reduction in the $\frac{\text { F.E.V.1 }}{\text { F.V.C. }}$ ratio was seen in only three patients. The M.B.C., V.C., and mixing efficiency were reduced in only three patients. The arterial blood $\mathrm{PCO}_{2}$ was raised in one patient, who had marked impairment in ventilatory function. Thus obstructive airway disease was seen less frequently than pulmonary diffusion abnormalities in the patients of this series.

The compliance estimations, especially when these were related to lung volumes, showed that the lungs of several patients were stiffer than normal. Thus a restrictive defect in pulmonary function was present. This would account for the low vital capacities of some patients who did not have airflow obstruction, e.g., patients 9 and 14. Abnormal tissue scattered diffusely throughout the lungs makes them less distensible. Williams $(1961 ; 1963)$ showed that the acute illnesses of farmer's lung may be produced by the inhalation of mouldy hay extracts in patients with farmer's lung. In these reactions, a temporary fall in static compliance and a definite but less marked fall in vital capacity and diffusing capacity were seen. The short duration of these changes (hours) suggested that a 
reversible condition, e.g., of inflammatory character, occurred. The acute illnesses had all subsided in the patients now described. It is unlikely therefore that the same mechanism is responsible for the low compliances seen. Histological studies show diffuse granulomatous infiltration and fibrosis in the lungs of these patients. Either may be associated with a low compliance (Lyons, 1958; Marshall and Dubois, 1956) and probably account for the changes seen.

The differences between the static and dynamic compliances in a few patients suggested that in normal breathing the lung was not expanding uniformly, probably due to some bronchiolar obstruction. When the respiratory rate is rapid, air cannot enter the smaller airways if they are partly blocked, and the tidal volume is served by the remaining larger airways whose alveoli become overdistended. The lung appears more rig:d (Otis, McKerrow, Bartlett, Mead, McIlroy, Selverstone, and Radford, 1956). The patients who showed this phenomenon markedly also had slight impairment in the $\frac{\text { F.E.V.1 }}{\text { F.V.C. }}$ ratio.

Frank (1958) noted that patients with farmer's lung with high or normal vital capacities might be breathless. This could be explained by the low pulmonary diffusing capacities. All patients with effort dyspnoea studied had impairment in the $D_{L_{c o}}$ whereas only $25 \%$ of them had low vital capacities. The vital capacity and maximum breathing capacity measurements described by previous observers were probably the least abnormal aspects of the pulmonary physiology of this condition.

The lung biopsy specimens described show that the granulomatous and fibrotic lesions infiltrate and distort the walls of the alveoli and bronchioles. Involvement of the alveoli will give rise to the physiological features of the alveolar-capillary block syndrome. Involvement of the bronchioles will produce an obstructive pattern of abnormal pulmonary function as seen in a few patients in this series.

The severity of the breathlessness in these patients was closely related to the impairment in pulmonary diffusing capacity and also (but less closely) to the reduction in static lung compliance. It was not closely related to the reduction in ventilatory function. If the sensation of dyspnoea is related to the ratio of the air requirements for exercise and the maximum breathing capacity, then the breathlessness in farmer's lung depends on the increased air requirement as a result of the diffusion defect rather than to a reduction in ventilatory capacity. Another factor which may cause exercise hyperventilation may be excessive stimulio from stretch reflexes in the 'stiff' lungs. The $D_{L_{c o}}$ 을 and pulmonary compliance are of value in the assessment of disability in these patients.

Lung function abnormalities were present in patients with farmer's lung with effort dyspnoeas although the chest radiographic shadowing hado cleared. At this stage, therefore, function studies were useful in the diagnosis and assessment of the extent of the disability, while radiographs were useless. The poor correlation between the radio logical and functional changes is further shown ${ }^{\infty}$ by patient 12 , who had normal effort tolerance i virtually normal pulmonary function studies, and abnormal radiological appearances consistent witho farmer's lung at that time.

It is impossible to say that a patient has farmer'ses lung from lung function studies alone. Othero diseases, e.g., asbestosis, sarcoidosis, scleroderma $\overrightarrow{\mathbb{D}}$ beryllium granulomatosis, and idiopathic diffuse interstitial pulmonary fibrosis, may have similar functional abnormalities. However, a low diffus $\vec{\imath}$ ing capacity in the absence of severe airflowe obstruction in a patient exposed to mouldy hay dust must be taken as strong suggestive evidence of farmer's lung, irrespective of the pulmonary radiological changes. Asthma may be worse aftero exposure to mouldy hay dust. Here the typica physiological finding is bronchial airway obstruc을 tion which may be reversed by isoprenaline. This, will distinguish it from farmer's lung.

\section{SUMMARY}

Lung function studies are described in 16 patients with farmer's lung who had recovered from theif acute illnesses. Residual effort dyspnoea was present in 12 patients and was usually associated with evidence of impaired pulmonary diffusing capacity, arterial oxygen desaturation at rest whicho increased on effort and rose to $100 \%$ when pure oxygen was breathed, sometimes a low statios compliance, relatively slight impairment in venti latory function, usually no airflow obstruction reversible with isoprenaline, and a high resting minute volume. These results were compatible with the 'alveolar-capillary block syndrome'. A few patients had pulmonary hyperinflation, defective gas mixing, and more marked ventilatory impaire ment, suggesting obstructive lesions in the smale airways.

The pulmonary function changes were $\operatorname{com}_{0}^{0}$ patible with the histological changes described They were often present when the chest radio $\overrightarrow{0}$ graph had returned to normal and appear helpfug 
in the diagnosis and assessment of disability in farmer's lung.

I would like to thank Professor J. G. Scadding and Dr. F. J. Prime for their generous help and encouragement. Dr. C. J. Fuller and Dr. J. L. Livingstone very kindly referred most of the patients studied. I am indebted to Mr. M. Foskett and Miss V. Scott for technical help.

\section{REFERENCES}

Austrian, R., McClement, J. H., Renzetti, A. D., Jr., Donald, K. W. Riley, R. L., and Cournand, A. (1951). Clinical and physiologic features of some types of pulmonary diseases with impairment of alveolar-capillary diffusion. Amer. J. Med., 11, 667.

Baldus, W. P., and Peter, J. B. (1960). Farmer's lung: report of two cases. New Engl. J. Med., 262, 700.

Baldwin, E. deF., Cournand, A., and Richards, D. W., Jr. (1948). Pulmonary insufficiency. I. Physiological classification, clinical methods of analysis, standard values in normal subjects. Medicine (Baltimore), 27, 243 . (Baltimore), 27, 243. (1949). Pulmonary insufficiency. II. A study of thirty-nine cases of pulmonary fibrosis. Ibid., 28, 1 .

Bernstein, L., D'Silva, J. L., and Mendel, D. (1952). The effect of the rate of breathing on the maximum breathing capacity determined with a new spirometer. Thorax, 7, 255.

Brown, L., Parrot, H., and Porter, E. C. (1958). Farmer's lung-case report. J. Maine med. Ass., 49, 447.

Campbell, E. J. M., and Howell, J. B. L. (1960). Simple rapid methods of estimating arterial and mixed venous $\mathrm{pCO}_{2}$. Brit. med. J., $1,458$. Campbell, J. M. (1932). Acute symptoms following work with hay.

Cooper, I. A., and Greenaway, T. M. (1961). Farmer's lung: a case report. Med. J. Aust., $2,980$.

Davies, H., Williams, J., and Wood, P. (1962). Lung stiffness in states of abnormal pulmonary blood flow and pressure. Brit. Heart J., $24,129$.

Dickie, H. A., and Rankin, J. (1958). Farmer's lung: an acute granulomatous interstitial pneumonitis occurring in agricultural workers. J. Amer. med. Ass., 167, 1069.

Fawcitt, R. (1938a). The roentgenological recognition of certain bronchomycoses involving occupational risks. Amer. J. Roentgenol., 39, 19 .

(1938b). Occupational diseases of the lungs in agricultural workers. Brit. J. Radiol., 11, 378.

Frank, R.C. (1958). Farmer's lung: a form of pneumoconiosis due to organic dusts. Amer. J. Roentgenol., 79, 189.
Fuller, C. J. (1953). Farmer's lung: a review of present knowledge. Thorax, 8, 59

Gandevia, B., and Hugh-Jones, P. (1957). Terminology for measurements of ventilatory capacity. Ibid., 12, 290 .

Gilson, J. C., and Hugh-Jones, P. (1949). The measurement of the total lung volume and breathing capacity. Clin. Sci., 7, 185 .

Lim, T. P. K., and Luft, U. C. (1959). Alterations in lung compliance and functional residual capacity with posture. J. appl. Physiol., 14, 164.

Lyons, H. A. (1958). Pulmonary compliance in granulomatous disease of the lung. Amer. J. Med., 25, 23.

MacNamara, J., Prime, F. J., and Sinclair, J. D. (1959). An assessment of the steady-state carbon monoxide method of estimating pulmonary diffusing capacity. Thorax, 14, 166

Marshall, R. (1957). The physical properties of the lungs in relation to the subdivisions of lung volume. Clin. Sci., 16, 507 .

- and Dubois, A. B. (1956). The viscous resistance of lung tissue in patients with pulmonary disease. Ibid., 15, 473.

Motley, H. L. (1958). Studies on the nature of the arterial blood oxygen unsaturation in chronic pulmonary disease. Dis. Chest,

National Academy of Sciences-National Research Council (1958). Handbook of Respiration, 1 st ed., ed. D. S. Dittmer and R. M. Grebe, p. 57. Saunders, Philadelphia.

Needham, C. D., Rogan, M. C., and McDonald, I. (1954). Normal standards for lung volumes, intrapulmonary gas-mixing, and maximum breathing capacity. Thorax, 9, 313 .

Otis, A. B., McKerrow, C. B., Bartlett, R. A.. Mead, J., McIlroy M. B., Selverstone, N. J., and Radford, E. P. (1956). Mechanical factors in distribution of pulmonary ventilation. J. appl. Physiol. $8,427$.

Pestalozzi, C. (1957). Un caso di malattia dei trebbiatori. Dermatologica (Basel), 115, 728.

Read, J., and Williams, R. S. (1959). Pulmonary ventilation-blood flow relationships in interstitial disease of the lungs. Amer. J. Med., 27, 545.

Seal, R. M. E. (1962). Farmer's lung. Tubercle (Lond.), 43, 330.

Staines, F, H., and Forman, J. A. S. (1961). A survey of " farmer's lung." J. Coll. gen. Pract., 4, 351 .

Studdert, T. C. (1953). Farmer's lung. B it. med. J., 1, 1305.

Totten, R. S., Reid, D. H. S., Davis, H. D., and Moran, T. J. (1958). Farmer's lung: report of two cases in which lung biopsies were performed. Amer. J. Med., 25, 803.

Van Slyke, D. D., and Neill, J. M. (1924). The determination of gases in blood and other solutions by vacuum extraction and manometric measurement. J. biol. Chem., 61, 523.

- and Sendroy, J., Jr. (1928). Studies of gas and electrolyte equilibria in blood. Ibid., 79, 781 .

Williams, J. V. (1961). Inhalation tests with hay and fungi in patients with farmer's lung. Acta allerg. (Kbh.), 16, 77.

(1963). Inhalation and skin tests with extracts of hay and fungi in patients with farmer's lung. Thorax, 18, 182

Wright, B. M. (1955). A respiratory anemometer. J. Physiol., Lond., $127,25 P$.

and McKerrow, C. B. (1959). Maximum forced expiratory flow rate as a measure of ventilatory capacity. B:it. med. J., 2, 1041 . 